\title{
ANALISIS PENGARUH KUALITAS JASA TERHADAP KEPUASAN PADA INDUSTRI PENDIDIKAN DI YOGYAKARTA*)
}

\author{
Munjiati Munawaroh \\ Universitas Muhammadiyah Yogyakarta
}

\begin{abstract}
This research evaluates the effect of quality service on customer satisfaction in program studies of university that are granted with accreditation rate either A or B from Badan Akreditasi Nasional. It also attempts to evaluate different quality service from program studies of university that are granted with accreditation rate either $A$ or $B$, and to evaluate different quality service from program studies of university that are granted with accreditation in same rated. Quality service is measured with SERVQUAL in five dimensions: reliability, responsiveness, assurance, empathy and tangibles.

The results show that customer satisfaction is affected by assurance, tangibles and reliability dimension. It also show that quality service is not different in program studies of university that are granted with accreditation rate either $A$ or $B$ in reliability, responsiveness, tangible and empathy dimension. The different quality services from program studies of university that are granted with accreditation rate either $A$ or $B$ is on assurance dimension. In program studies with same grant show that although they have accreditation rate $A$, they have different quality in five dimension, and in program studies that are granted with accreditation rate $B$, they have different quality in responsiveness, assurance and tangible dimension, but there are not different in empathy dimension.
\end{abstract}

Key word: quality service, reliability, responsiveness, assurance, and empathy tangibles, Badan Akreditasi Nasional

\section{LATAR BELAKANG}

Pada era globalisasi ini, kualitas dipandang sebagai salah satu alat untuk mencapai keunggulan kompetitif, karena kualitas merupakan salah satu faktor utama yang menentukan pemilihan produk dan jasa bagi konsumen. Tujuan dari organisasi bisnis adalah untuk menghasilkan barang dan jasa yang dapat memuaskan konsumen. Kepuasan konsumen akan tercapai apabila kualitas produk dan jasa yang diberikan sesuai dengan kebutuhannya.

Kualitas jasa yang baik merupakan hal yang sangat penting dalam menciptakan kepuasan pelanggan, namun untuk memahami bagaimana mengevaluasi kualitas yang diterima oleh konsumen tidaklah mudah. Kurtz dan Clow (1998) menyatakan bahwa kualitas jasa lebih sukar untuk dievaluasi dibandingkan dengan kualitas barang. Kualitas jasa tidak diciptakan melalui proses produksi dalam pabrik untuk kemudian diserahkan kepada konsumen sebagaimana kualitas barang. Sebagian besar kualitas jasa

*) Jurnal Siasat Bisnis Edisi No. 5 Vol. 2, Th. 2000 
diberikan selama penyerahan jasa terjadi dalam proses interaksi diantara konsumen dan terdapat kontak personil dengan penyelenggara jasa tersebut.

Perguruan tinggi di Indonesia sebagai salah satu organisasi jasa, saat ini mengalami suatu perubahan yang fundamental. Perubahan kurikulum, perubahan metode pengajaran, perubahan sistem paket semester menjadi sistem kredit semester, dan sebagainya berdampak antara lain pada lamanya masa studi serta kualitas lulusan yang lebih baik. Perubahan ini dilakukan untuk mengantisipasi perubahan lingkungan terutama dalam menyambut era globalisasi. Perubahan ini bukan hanya disebabkan karena pesatnya perkembangan ilmu, teknologi dan seni, melainkan juga karena perubahan ekspektasi masyarakat terhadap peranan perguruan tinggi dalam merintis hari depan bangsa dan negara.

Tuntutan terhadap perguruan tinggi dewasa ini bukan hanya sebatas kemampuan untuk menghasilkan lulusan yang diukur secara akademik, melainkan keseluruhan program dan lembaga-lembaga perguruan tinggi harus mampu membuktikan kualitas yang tinggi yang didukung oleh akuntabilitas yang ada. Bukti prestasi, penilaian, sertifikasi kualitas, keberhasilan alumni dalam mendapatkan pekerjaan yang sesuai dengan bidang ilmunya, serta hasil evaluasi juga dibutuhkan untuk memperoleh pengakuan dari masyarakat.

Untuk memenuhi tuntutan itu, maka perguruan tinggi melalui program-program studinya perlu memperoleh kepercayaan masyarakat dengan jaminan kualitas (quallity assurance), pengendalian kualitas (quality control), perbaikan kualitas (quality improvement). Jaminan, pengendalian, dan pembinaan atau perbaikan kualitas dapat diberikan kepada perguruan tinggi atau program studi yang telah dievaluasi secara cermat melalui proses akreditasi secara nasional (Badan Akreditasi Nasional Perguruan Tinggi, 1998).

Selain evaluasi kualitas yang dilakukan oleh BAN, perguruan tinggi sebagai salah satu organisasi jasa yang bergerak dibidang pendidikan, perlu juga melakukan evaluasi atas kualitas jasa dari konsumen, terutama mahasiswanya. Evaluasi kualitas jasa di perguruan tinggi dapat dilakukan untuk mengetahui apa yang sebenarnya diharapkan oleh mahasiswa dan apa yang selama ini dipersepsikan oleh mahasiswa atas kualitas jasa yang diterimanya. Seringkali terjadi perbedaan atau gap antara kualitas jasa yang diharapkan oleh mahasiswa dengan persepsi mahasiswa atas kualitas jasa yang diterimanya. Adanya gap tersebut menunjukkan bahwa kualitas jasa yang diterima oleh mahasiswa belum memenuhi harapannya. Besar kecilnya gap akan berpengaruh terhadap kepuasan konsumen (mahasiswa). Berdasarkan keadaan ini, maka perlu diteliti mengenai bagaimana pengaruh gap kualitas jasa terhadap kepuasan konsumen.

Adanya evaluasi kualitas perguruan tinggi melalui program-program studinya secara cermat dengan proses akreditasi secara nasional oleh BAN, menimbulkan anggapan bahwa diantara program studi yang 
memiliki peringkat akreditasi yang sama akan memiliki kualitas yang sama, dan diantara program studi yang memiliki peringkat akreditasi yang berbeda akan memiliki kualitas yang berbeda. Walaupun demikian, ada kemungkinan bahwa penilaian BAN berbeda dengan penilaian mahasiswa. Apabila terjadi perbedaan yang besar antara penilaian BAN dengan penilaian mahasiswa, ini bisa mengindikasikan beberapa hal, misalnya laporan yang dikirimkan oleh perguruan tinggi ke BAN tidak menunjukkan hal yang sebenarnya, atau evaluasi BAN yang kurang teliti. Untuk itulah perlu dianalisis adanya perbedaan gap kualitas jasa pada program studi perguruan tinggi yang mendapatkan peringkat akreditasi A dengan program studi perguruan tinggi yang mendapatkan peringkat $B$, dan adanya perbedaan gap kualitas jasa diantara program studi perguruan tinggi yang mendapatkan peringkat akreditasi yang sama.

\section{TINJAUAN PUSTAKA}

\section{Dimensi Kualitas Jasa}

Kualitas merupakan tingkat kesesuaian dengan persyaratan, dalam hal ini persyaratan pelanggan. Total quality service merupakan konsep tentang bagaimana menanamkan kualitas pelayanan pada setiap fase penyelenggaraan jasa yang melibatkan semua personel yang ada dalam organisasi (Handriana, 1998).

Beberapa dimensi kualitas jasa diteliti oleh banyak ahli. Parasuraman dkk. (1985) pada riset eksploratori mereka meneliti kualitas jasa dan faktorfaktor yang menentukannya. Mereka menemukan 5 dimensi kualitas jasa, yaitu:

1. Reliability: kemampuan untuk memberikan jasa dengan segera dan memuaskan.

2. Responsiveness: kemampuan untuk memberikan jasa dengan tanggap.

3. Assurance: kemampuan, kesopanan, dan sifat dapat dipercaya yang dimiliki oleh para staf, bebas dari bahaya, resiko dan keragu-raguan.

4. Emphaty: kemudahan dalam melakukan hubungan komunikasi yang baik dan memahami kebutuhan pelanggan.

5. Tangibles: fasilitas fisik, perlengkapan, pegawai dan sarana komunikasi.

Penelitian Shank dkk. (1995) menemukan kualitas pelayanan yang terbagi menjadi tiga dimensi: respek terhadap mahasiswa, pengetahuan dosen dan lingkungan fisik universitas/perguruan tinggi (Handriana 1998).

Lehtinen dan Lehtinen (1982) membagi dimensi kualitas jasa menjadi 3, yaitu: interactive quality yang berkenaan dengan kontak personal, physical quality yang berkenaan dengan fasilitas fisik yang mendukung kulitas jasa dan corporate quality yang melibatkan image perusahaan. (Babacus dan Boller, 1992). 
Gronroos (1984) membagi dimensi kualitas jasa menjadi 2, yaitu: technical (kualitas teknik) dan functional (kualitas fungsional) Kualitas teknik adalah apa yang pelanggan dapatkan, sedangkan kualitas fungsionalmengacu pada bagaimana mereka menerima jasa pelayanan. (Babacus dan Boller, 1992).

Hedvall dan Peltschik (1989) membagi dimensi kualitas jasa menjadi 2, yaitu: wilingness and ability to serve (kemauan dan kemampuan untuk melayani) dan physical and psychological access (akses fisik dan psikhologis) (Babacus dan Boller, 1992).

Babakus dan Boller (1992) dalam riset yang dilakukan pada perusahaan pengguna jasa industri listrik dan gas di metropolitan Amerika Selatan gagal mereplikasi penelitian Parasuraman dkk. (1985) yang menggunakan 5 dimensi kualitas jasa. Berdasarkan hasil dari analisis faktor yang dilakukannya, hanya ditemukan 2 dimensi kualitas jasa. Hal ini sejalan dengan penemuan Carman (1990), yang menemukan indikasi kemungkinan dimensi kualitas jasa terdiri dari 5-9 dimensi, tergantung pada jenis industri jasa/tipe jasa yang akan diukur (Babacus dan Boller, 1992).

Dari berbagai penelitian tersebut dapat disimpulkan bahwa dimensi kualitas jasa akan tergantung pada jenis industri jasa yang akan dinilai. Pada jenis industri jasa yang berbeda kemungkinan memiliki dimensi kualitas yang berbeda pula.

\section{Pengukuran Kualitas Jasa}

Untuk menganalisis kualitas jasa dapat dilakukan dengan mengkuantifikasi dimensi kualitas dengan menggunakan skala Likert pada kuesioner yang disebarkan kepada responden. Zeithaml, dkk. (1988) mengukur kualitas jasa dengan mengetahui perbedaan/gap antara harapan dengan persepsi pelanggan. Hal ini sesuai dengan definisi kualitas pelayanan, yaitu derajat perbedaan antara harapan pelanggan dengan persepsi pelanggan terhadap kinerja jasa yang diterimanya.

Berbeda dengan Parasuraman, dkk (1985), Cronin dan Taylor (1992) mengemukakan konsep SERVPERF untuk mengukur kualitas jasa, yaitu kualitas pelayanan secara langsung dipengaruhi oleh persepsi pelanggan terhadap kinerja. Konsep ini didukung juga oleh beberapa peneliti, yaitu Babakus dan Boller (1992), Teas (1994), dan sebagainya.

\section{Kepuasan}

Kotler (1997) mendefinisikan kepuasan sebagai perasaan suka atau kecewa seseorang sebagai hasil dari perbandingan antara persepsi atas kinerja produk dengan harapannya. Definisi ini mengandung pengertian bahwa kepuasan merupakan fungsi kinerja yang dipersepsikan dengan harapan. Pengertian kepuasan ini didukung juga oleh Zeithaml, dkk (1993). 
Dalam kaitannya dengan hubungan antara kualitas jasa dan kepuasan, Qamari (1998) melakukan evaluasi kualitas jasa rumah sakit dan penerapan konsep QFD pada 4 rumah sakit di DIY, yaitu RSUP Dr. Sardjito, RS Panti Rapih, RS Bethesda dan PKU Muhammadiyah. Penelitian ini menganalisis kualitas pelayanan rumah sakit kelas VIP, dengan melihat gap antara pihak rumah sakit dengan para pemakai jasanya. Kualitas pelayanan yang diteliti pada rumah sakit adalah pada sisi kerja para medik dan non medik dalam mengobati, merawat dan mengusahakan kesembuhan dan kesehatan pasien. Sedangkan dari pihak pemakai jasa, kualitas pelayanan yang diteliti adalah pada penampilan fisik rumah sakit, fasilitas yang tersedia dan kenyamanan. Hasilnya menunjukkan bahwa dari kelima dimensi kualitas jasa, variabel responsiveness merupakan variabel yang terpenting yang berpengaruh terhadap kepuasan pelanggan.

Kettinger dan Lee (1994) melakukan penelitian tentang kualitas jasa yang dipersepsikan dan fungsi kepuasan pengguna jasa informasi. Penelitian ini menggunakan SERVQUAL untuk mendapatkan informasi secara spesifik tentang kepuasan user atas fungsi jasa informasi. Mereka mendukung pernyataan Oliver (1980) yang menyatakan bahwa kepuasan merupakan fungsi diskonfirmasi antara harapan dan persepsi atas kinerja (Kettinger dan Lee, 1994). Hasil penelitian ini menunjukkan bahwa ternyata hanya variabel reliability dan emphaty saja yang merupakan prediktor dari kepuasan konsumen.

Dari uraian tersebut, peneliti mengemukakan hipotesis, bahwa terdapat hubungan positif antara gap (selisih antara kinerja kualitas jasa yang dipersepsikan dengan kualitas jasa yang diharapkan oleh mahasiswa) kualitas jasa, dengan kepuasan mahasiswa. Secara terperinci, beberapa hipotesis yang dapat dikemukakan adalah:

H1 : Apabila gap reliability semakin tinggi, maka kepuasan mahasiswa akan meningkat.

H2 : Apabila gap responsiveness semakin tinggi, maka kepuasan mahasiswa akan meningkat.

H3 : Apabila gap assurance semakin tinggi, maka kepuasan mahasiswa akan meningkat.

H4 : Apabila gap emphaty semakin tinggi, maka kepuasan mahasiswa akan meningkat.

H5 : Apabila gap tangible semakin tinggi, maka kepuasan mahasiswa akan meningkat.

\section{Perbedaan Kualitas dalam Industri Jasa}

Dimensi kualitas jasa tergantung pada jenis industri jasa yang akan dinilai. Pada jenis industri jasa yang berbeda kemungkinan memiliki dimensi kualitas yang berbeda pula. Dengan menggunakan pengukuran 
pada dimensi yang sama, tingkat kualitas jasa akan berbeda pada jenis industri jasa yang berbeda. Bahkan diantara industri jasa yang sejenis, tingkat kualitas jasa mungkin berbeda. Beberapa penelitian telah membuktikan hal ini.

Musa (1996) melakukan penelitian tentang Total Quality Service pada organisasi mutimedia pada TVRI dan RCTI. Variabel yang dinilai adalah cost efficiency, quality, dependability, flexibility, time based competition dan support service. Hasilnya menunjukkan bahwa TVRI maupun RCTI sama-sama berkeinginan untuk memberikan servis khusus dengan menggunakan strategi dari keenam variabel tersebut, namun dengan intensitas yang berbeda. Implementasi cost efficiency di TVRI lebih banyak dilakukan dibandingkan dengan RCTI. Kualitas yang dipersepsikan oleh pelanggan, dependability, flexibility, time based competition dan support service di RCTI lebih tinggi dibandingkan dengan di TVRI. Secara keseluruhan, ternyata sebagian besar dari keenam variabel tersebut menunjukkan bahwa RCTI sebagai organisasi privat dalam lebih baik daripada TVRI sebagai organisasi publik.

Handriana (1998) meneliti mengenai analisis perbedaan harapan kualitas jasa pada lembaga pendidikan tinggi di Surabaya. Penelitian ini mereplikasi dari penelitian yang dilakukan oleh Shank dkk. (1995) yang berjudul: Expectation: Do we know our students expect in Quality education? Berdasarkan penelitian Shank dkk. (1995) yang membagi kualitas pelayanan menjadi tiga dimensi: respek terhadap mahasiswa, pengetahuan dosen dan lingkungan fisik universitas/perguruan tinggi, maka dalam penelitiannya, Handriana (1998) menganalisis berdasarkan gap antara kualitas jasa yang diharapkan oleh mahasiswa dan persepsi dosen atas kualitas jasa yang diharapkan oleh mahasiswa.

Hasilnya menunjukkan bahwa tiga gap terbesar terjadi dalam hal pengetahuan dosen, antara lain seharusnya dosen membantu mahasiswa membuat jadwal kelas dan harapan mahasiswa bahwa dosen seharusnya mempunyai pengetahuan akan kesempatan kerja, serta perlunya dosen memperhatikan persoalan akademis mahasiswanya. Harapan mahasiswa terhadap kualitas yang terbesar adalah dari fasilitas kampus harus memadahi, dosen harus bersedia membantu mahasiswa dalam hal pelajaran. Sedangkan menurut persepsi dosen yang terbesar adalah mahasiswa harus menerima jasa yang tepat dari dosen, misalkan materi dan jam kuliah, fasilitas kampus memadahi, dan fasilitas kampus aman bagi mahasiswa. Mahasiswa PTN memiliki harapan kualitas jasa yang sama dengan mahasiswa PTS. Tingkatan semester mahasiswa tidak berpengaruh terhadap harapan mahasiswa akan kualitas jasa.

Dalam penelitian ini, penulis akan meneliti tentang kualitas jasa pendidikan tinggi di Yogyakarta. Berbeda dengan penelitian Handriana (1998), penelitian ini tidak mengklasifikasi perguruan tinggi berdasarkan 
pengelolanya, yaitu perguruan tinggi negeri dan swasta, tetapi berdasarkan perbedaan program studi perguruan tinggi yang mendapatkan peringkat akreditasi A dan B sesuai dengan klasifikasi Badan Akreditasi Nasional.

Penelitian ini menekankan pada perbedaan gap kualitas jasa antara mahasiswa dari program studi pada program studi perguruan tinggi yang mendapatkan peringkat akreditasi $A$ dengan program studi perguruan tinggi yang mendapatkan peringkat $B$, dan adanya perbedaan gap diantara program studi perguruan tinggi yang mendapatkan peringkat akreditasi yang sama. Dengan demikian, peneliti mengemukakan hipotesis:

H6: Ada perbedaan gap antara program studi perguruan tinggi yang mendapatkan peringkat akreditasi A dengan yang mendapat peringkat akreditasi $B$.

H7: Ada perbedaan gap antar program studi perguruan tinggi yang mendapatkan peringkat akreditasi yang sama.

\section{METODE PENELITIAN}

\section{Pengumpulan Data dan Pemilihan Sampel}

Data diambil dari mahasiswa pada program studi perguruan tinggi yang mewakili universitas negeri, universitas swasta, sekolah tinggi dan institut yang memiliki peringkat akreditasi A dan B di Yogyakarta. Akademi tidak diambil sampelnya karena pada saat penelitian ini berlangsung, akreditasi terhadap akademi belum dilakukan.

Data diperoleh dengan menggunakan kuesioner. Jumlah sampel yang diambil sebanyak 432 responden mahasiswa. Prosedur pengambilan sampelnya dengan purposive sampling dan convenience sampling. Dari 432 kuesioner, terdapat 4 kuesioner yang tidak layak, sehingga tinggal 428 kuesioner yang bisa dianalisis.

\section{Pengukuran Variabel Dependen dan Independen}

Variabel dependen yang digunakan dalam penelitian adalah kepuasan, sedangkan variabel independen terdiri dari: gap reliability $\left(X_{1}\right)$, gap responsiveness $\left(X_{2}\right)$, gap assurance $\left(X_{3}\right)$, gap emphaty $\left(X_{4}\right)$, gap tangibles $\left(X_{5}\right)$.

Pertanyaan-pertanyaan dalam kuesioner merupakan jenis pertanyaan tertutup dengan metode pengukuran skala Likert yang terdiri dari lima pilihan jawaban, yaitu sangat setuju (bernilai 5), setuju (bernilai 4), netral (bernilai 3), tidak setuju (bernilai 2) dan sangat tidak setuju (bernilai 1). Agar data yang diperoleh dengan cara penyebaran kuesioner tersebut valid dan reliabel, maka dilakukan uji validitas dengan menguji homogenitas item, dan reliabilitas terhadap butir-butir pertanyaan/kuesioner dengan menghitung Cronbrach alpha. Instrumen untuk mengukur masing-masing variabel dikatakan reliabel jika memiliki Cronbrach alpha lebih besar dari 
0.50 (Nunnally, 1967). Dari hasil uji reliabilitas dan validitas menunjukkan bahwa variabel-variabel tersebut reliabel dan valid.

\section{HASIL DAN PEMBAHASAN}

\section{Pengaruh Kualitas Jasa terhadap Kepuasan}

Hasil analisis regresi menunjukkan bahwa kepuasan mahasiswa hanya dipengaruhi oleh variabel $X_{3}$ (gap assurance), $X_{5}$ (gap tangibles) dan $X_{1}$ (gap reliability)., tetapi tidak dipengaruhi oleh variabel $X_{2}$ (gap responsiveness) dan $X_{4}$ (gap emphaty). $R$ Square untuk model ini adalah 43,633\%. Ternyata hasil regresi hanya mendukung hipotesis 1,3 dan 5 . Hasil dari pengujian menggunakan regresi linier berganda yang ditunjukkan pada tabel 1., membentuk persamaan:

$Y=3.99241+0.199902 X_{1}-0.019756 X_{2}+0.219518 X_{3}+0.029160 X_{4}+0.259104 X_{5}$

Tabel 1

Pengaruh Kualitas Jasa Terhadap Kepuasan

\begin{tabular}{|l|c|c|c|c|}
\hline \multicolumn{1}{|c|}{ VARIABLE } & KOEFISIEN & $\begin{array}{c}\text { KESALAHA } \\
N \\
\text { STANDAR }\end{array}$ & $T$ & $P$ \\
\hline Gap reliability $\left(X_{1}\right)$ & 0.199902 & 0.061181 & -3.267 & 0.0012 \\
\hline Gap responsiveness $\left(X_{2}\right)$ & -0.019756 & 0.038950 & -0.507 & T.S \\
\hline Gap assurance $\left(X_{3}\right)$ & 0.219518 & 0.051715 & 4.245 & 0.0000 \\
\hline Gap emphaty $\left(X_{4}\right)$ & 0.029160 & 0.041972 & 0.695 & T.S \\
\hline Gap tangibles $\left(X_{5}\right)$ & 0.259104 & 0.053063 & 4.883 & 0.0000 \\
\hline Konstanta $\left(\beta_{0}\right)$ & 3.992410 & 0.055463 & 71.983 & 0.0000 \\
\hline
\end{tabular}

$\mathrm{R}^{2}=0.43633 ;$ Adjusted $\mathrm{R}^{2}=0.42965 ; \mathrm{n}=428 ; \mathrm{F}=65.33309 ;$ sign $\mathrm{F}=0.0000$

Dari persamaan tersebut, variabel $X_{3}$ (gap assurance) memiliki pengaruh paling kuat terhadap kepuasan yang ditunjukkan oleh koefisien yang paling besar, diikuti oleh variabel $X_{5}$ (gap tangibles) dan $X_{1}$ (gap reliability).

Bukti empiris tidak mendukung hipotesis 2 dan 4, karena ternyata hasilnya menunjukkan bahwa koefisien regresi tidak signifikan, yang berarti kepuasan tidak dipengaruhi oleh variabel gap responsiveness dan gap emphaty. Ini sejalan dengan yang diungkapkan oleh Tjiptono (1999), bahwa meskipun fakta menunjukkan bahwa terjadi kegagalan penyampaian jasa, namun pelanggan bisa merasa puas. Hal ini disebabkan karena kriteria kepuasan konsumen tidak ditentukan oleh terpenuhinya semua harapan. Dengan 
demikian, maka kepuasan konsumen dapat tercapai meskipun tidak semua harapannya terpenuhi.

\section{Uji Beda Gap antara Program Studi Perguruan Tinggi yang Mendapat- kan Akreditasi A dan B.}

Hasil uji beda ternyata menunjukkan bahwa pada sebagian besar dimensi kualitas jasa tidak ada perbedaan kualitas jasa antara program studi perguruan tinggi yang mendapatkan akreditasi $A$ dan $B$, yaitu pada dimensi reliability, responsiveness, emphaty dan tangible. Perbedaan antara program studi perguruan tinggi yang mendapatkan akreditasi A dan B justru terdapat pada variabel assurance. Secara lengkap, hasil uji t ditunjukkan pada tabel 2.

Tabel 2

Hasil t-test Perbedaan Means antara Program Studi Perguruan Tinggi yang Mendapatkan Akreditasi A dan B.

\begin{tabular}{|l|c|c|c|c|c|}
\hline \multicolumn{1}{|c|}{ VARIABEL } & $\begin{array}{c}\text { MEAN DAN } \\
\text { SD }\end{array}$ & $\begin{array}{c}\text { AKREDITASI } \\
\text { A }\end{array}$ & $\begin{array}{c}\text { AKREDITASI } \\
\text { B }\end{array}$ & T & P \\
\hline \multirow{2}{*}{ G. reliability $\left(X_{1}\right)$} & Mean & -1.0016 & -1.0090 & -0.1 & 0.916 \\
& SD & 0.684 & 0.767 & & \\
\hline \multirow{2}{*}{ G. responsiveness $\left(X_{2}\right)$} & Mean & -1.3991 & -1.3026 & 1.02 & 0.307 \\
& SD & 1.005 & 0.931 & & \\
\hline \multirow{2}{*}{ G. assurance $\left(X_{3}\right)$} & Mean & -1.2296 & -1.0551 & 2.11 & 0.035 \\
\hline \multirow{2}{*}{ G. emphaty $\left(X_{4}\right)$} & SD & 0.832 & 0.871 & & \\
\hline \multirow{2}{*}{ G. tangibles $\left(X_{5}\right)$} & Mean & -1.5594 & -1.6085 & -0.51 & 0.607 \\
& SD & 0.901 & 1.050 & & \\
\hline
\end{tabular}

Hasil dari penelitian ini menunjukkan bahwa penilaian kualitas jasa oleh mahasiswa sebagai konsumen yang menikmati kualitas jasa secara langsung ternyata berbeda dengan penilaian Badan Akreditasi Nasional. Ini ditunjukkan oleh tidak adanya perbedaan kualitas jasa antara program studi yang terakreditasi A dengan $\mathrm{B}$, yaitu pada tangible, responsiveness reliability dan emphaty, dimana keempatnya merupakan dasar penilaian Badan Akreditasi Nasional untuk membedakan penilaian peringkat akreditasi.

Perbedaan antara penilaian mahasiswa dengan BAN dianalisis dengan menelusuri proses akreditasi. Proses akreditasi diawali dengan dilaksanakannya penilaian secara intern oleh lembaga pendidikan itu sendiri, yang 
formatnya disiapkan oleh BAN-PT sebagai instrumen penilaian program studi dalam bentuk borang akreditasi. Penilaian internal itu disampaikan kepada BAN-PT untuk diteliti ulang sebagai upaya penilaian validasi data/informasi yang telah disampaikan. Selanjutnya diadakan kunjungan oleh anggota BANPT, satgas wilayah, atau kelompok pakar yang ditunjuk oleh pimpinan BAN-PT untuk kemudian ditentukan hasil penilaiannya.

Penilaian secara intern oleh lembaga pendidikan itu sendiri tersebut memungkinkan terjadinya kekeliruan ataupun manipulasi data, meskipun pada akhirnya BAN melakukan penelitian ulang untuk validasi data dan informasi. Hal ini bisa disebabkan karena banyaknya program studi perguruan tinggi di Indonesia yang dinilai oleh BAN, sehingga memungkinkan adanya kekurangtelitian dalam proses validasi data dan informasi.

\section{Uji Beda Gap antara Program Studi Perguruan Tinggi yang Memiliki Pe- ringkat Akreditasi Sama. \\ Uji Beda Gap antar Program Studi Perguruan Tinggi yang Mendapatkan Akreditasi $A$.}

Hasil uji beda menunjukkan bahwa terdapat perbedan kualitas jasa antara program studi perguruan tinggi yang mendapatkan akreditasi $\mathrm{A}$ pada kelima dimensi seperti yang ditunjukkan pada tabel 3.

Tabel 4

Uji Beda Gap antar Program Studi Perguruan Tinggi yang Mendapatkan Akreditasi A

\begin{tabular}{|l|c|c|c|c|}
\hline \multicolumn{1}{|c|}{ VARIABEL } & MEAN & SD & F RATIO & P \\
\hline G. reliability $\left(\mathrm{X}_{1}\right)$ & 3.3632 & 0.5823 & 14.5700 & 0.0000 \\
\hline G. responsiveness $\left(\mathrm{X}_{2}\right)$ & 3.1395 & 0.8336 & 6.4194 & 0.0003 \\
\hline G. assurance $\left(\mathrm{X}_{3}\right)$ & 3.2500 & 0.6979 & 12.2293 & 0.0000 \\
\hline G. emphaty $\left(\mathrm{X}_{4}\right)$ & 2.9685 & 0.7363 & 7.5324 & 0.0001 \\
\hline G. tangibles $\left(\mathrm{X}_{5}\right)$ & 3.5858 & 0.7150 & 34.5685 & 0.0000 \\
\hline
\end{tabular}

Dari hasil uji beda gap untuk kelima dimensi pada program studi yang mempunyai peringkat akreditasi A menunjukkan bahwa meskipun sama-sama mendapatkan peringkat akreditasi $A$, masing-masing program studi memiliki perbedaan gap kualitas jasa pada kelima dimensi kualitas jasa. 


\section{Uji Beda Gap antar Program Studi Perguruan Tinggi yang Mendapatkan Akreditasi B.}

Hasil uji beda gap untuk kelima dimensi pada program studi yang mempunyai peringkat akreditasi $B$ menunjukkan bahwa meskipun samasama mendapatkan peringkat akreditasi $B$, masing-masing program studi memiliki perbedaan gap kualitas jasa pada dimensi reliability, assurance, responsiveness dan tangible, namun memiliki kesamaan gap kualitas jasa pada dimensi emphaty, sebagaimana ditunjukkan pada tabel 4.

Dengan demikian dapat disimpulkan bahwa hipotesis ke tujuh didukung untuk kelima dimensi pada program studi yang mempunyai peringkat akreditasi $A$ dan didukung untuk program studi yang mempunyai peringkat akreditasi B pada dimensi reliability, assurance, responsiveness dan tangible, namun tidak teruji pada dimensi emphaty.

Perbedaan maupun persamaan gap antar program studi perguruan tinggi yang mendapatkan peringkat akreditasi B pada kelima dimensi tersebut bisa saja terjadi, mengingat banyaknya komponen yang dinilai, yang terdiri dari input, proses dan output. Dengan demikian, hasil total/akhir penilaian bisa saja memiliki range yang masuk dalam katagori akreditasi yang sama, meskipun hasil penilaian pada masing-masing komponen berbeda. Hasil empiris menunjukkan bahwa dimensi emphaty antar program studi yang mendapatkan peingkat akreditasi B tidak berbeda.

Tabel 4

Uji Beda Gap antar Program Studi Perguruan Tinggi yang Mendapatkan Akreditasi B

\begin{tabular}{|l|c|c|c|c|}
\hline \multicolumn{1}{|c|}{ VARIABEL } & MEAN & SD & F RATIO & P \\
\hline G. reliability $\left(\mathrm{X}_{1}\right)$ & 3.3378 & 0.6411 & 3.8772 & 0.0101 \\
\hline G. responsiveness $\left(\mathrm{X}_{2}\right)$ & 3.2077 & 0.9105 & 3.6889 & 0.0129 \\
\hline G. assurance $\left(\mathrm{X}_{3}\right)$ & 3.3744 & 0.7367 & 5.6915 & 0.0009 \\
\hline G. emphaty $\left(\mathrm{X}_{4}\right)$ & 2.8479 & 0.8820 & 2.0624 & 0.1066 \\
\hline G. tangibles $\left(\mathrm{X}_{5}\right)$ & 3.3991 & 0.7134 & 10.4035 & 0.0000 \\
\hline
\end{tabular}

\section{SIMPULAN}

Hasil penelitian ini menunjukkan bahwa kepuasan konsumen dipengaruhi oleh dimensi assurance, tangibles dan reliability. Hasil penelitian ini juga menunjukkan bahwa tidak ada perbedaan kualitas jasa antara program studi yang mendapatkan peringkat akreditasi A dan B pada dimensi reliability, responsiveness, tangible, dan emphaty. Perbedaan kualitas jasa antara program studi yang mendapatkan peringkat akreditasi $A$ dan $B$ hanya terdapat pada dimensi assurance. Pada program studi yang mendapat- 
kan peringkat akreditasi sama ternyata menunjukkan bahwa meskipun samasama mendapatkan peringkat akreditasi $A$, kualitas jasa masing-masing program studi berbeda pada kelima dimensi kualitas jasa. Pada program studi yang mempunyai peringkat akreditasi $\mathrm{B}$, dimensi reliability, responsiveness, assurance dan tangible, masing-masing program studi berbeda, namun tidak ada perbedaan pada dimensi emphaty.

\section{IMPLIKASI}

Penelitian ini diharapkan menambah wawasan pada aplikasi pengukuran kualitas jasa yang telah dilakukan Parasuraman dkk. (1985), pada industri jasa pendidikan tinggi. Dengan mendasarkan pembagian sampel berdasar akreditasi sebagai standar mutu perguruan tinggi di Indonesia saat ini, penelitian ini dapat memberikan gambaran mengenai kualitas jasa perguruan tinggi pada berbagai perguruan tinggi yang mendapatkan peringkat berbeda.

Penelitian ini dapat menjadi sumber informasi bagi perguruan tinggi yang ingin meningkatkan kualitas jasa agar lebih memuaskan mahasiswa khususnya dan konsumen pada umumnya, serta evaluasi perguruan tinggi dalam kaitannya dengan masalah akreditasi oleh Badan Akreditasi Nasional. Berdasarkan hasil penelitian ini, maka apabila perguruan tinggi ingin meningkatkan kepuasan mahasiswa, sebaiknya lebih memenuhi harapan mahasiswa tentang kualitas jasa pada dimensi reliability, tangibles dan assurance.

Hasil penelitian juga menunjukkan bahwa Badan Akreditasi Nasional sebagai badan yang bertugas memberikan penilaian kualitas dan sekaligus mengevaluasinya memiliki perbedaan penilaian dengan mahasiswa. Hal ini dapat dilihat dari adanya perbedaan dengan hasil pendapat mahasiswa pada item-item yang sesuai dengan komponen penilaian BAN, yaitu tidak ada perbedaan kualitas jasa antara program studi yang mendapatkan peringkat akreditasi A dengan B pada variabel reliability, responsiveness, tangible dan emphaty. Hasil dari penelitian ini menunjukkan bahwa perbedaan kualitas jasa antara program studi yang mendapatkan peringkat akreditasi $\mathrm{A}$ dengan B justru terdapat pada variabel assurance yang bukan menjadi dasar pembedaan peringkat akreditasi oleh BAN. Hasil penelitian ini diharapkan dapat dijadikan bahan evaluasi BAN dalam melakukan penilaian peringkat akreditasi.

\section{KETERBATASAN}

Penelitian ini memiliki keterbatasan. Sebagaimana yang telah diungkapkan oleh peneliti sebelumnya yang telah melakukan penelitian tentang kualitas jasa, pengukuran kualitas jasa dengan menggunakan gap 
memiliki keterbatasan. Pengukuran antara kinerja dan harapan yang dilakukan secara bersamaan, bisa menghasilkan permasalahan defisiensi skor, artinya ketika responden diminta memberikan penilaian atas harapan dan kinerja secara bersamaan, mereka cenderung memberikan skor pada harapan yang lebih tinggi dibandingkan dengan kinerja (Cronbach dan Furby, 1970; Wall dan Payne, 1973 dalam Babacus dan Boller, 1992). Mereka kemungkinan memberikan penilaian yang kurang obyektif. Dengan demikian, hasilnya bisa menjadi tidak akurat. Meskipun hal ini dapat terjadi, dalam penelitian ini penulis menemukan beberapa responden yang menjawab item pertanyaan kinerja yang melebihi harapannya.

Keterbatasan lainnya adalah untuk variabel kepuasan yang diukur secara bersamaan dengan variabel gap, juga akan menimbulkan bias, sehingga jawaban responden kemungkinan tidak akurat. Keadaan ini merupakan common method variance, yang sering kali terjadi pada penelitian survey.

Penelitian ini hanya mengukur gap ke lima saja, yaitu gap antara harapan konsumen dengan persepsi konsumen atas kinerja jasa, dimana gap ke lima ini tergantung pada empat gap yang lain yaitu: gap antara harapan pelanggan dengan persepsi manajemen atas harapan pelanggan, gap antara persepsi manajemen atas harapan pelanggan dengan spesifikasi kualitas jasa, gap antara spesifikasi kualitas jasa dengan kualitas jasa yang sebenarnya diberikan dan gap antara jasa yang diberikan dengan jasa yang dikomunikasikan dengan pelanggan. Untuk penelitian mendatang dapat diteliti juga keempat gap tersebut, sehingga analisis menjadi lebih mendalam untuk dapat menentukan gap ke berapa yang memiliki andil terebesar dalam mempengaruhi terjadinya gap ke lima ini. Hal ini dapat digunakan sebagai bahan evaluasi bagi perguruan tinggi yang ingin mengevaluasi kualitas jasanya, sehingga semakin dapat memenuhi harapan mahasiswanya.

Penelitian ini hanya dibatasi pada program studi perguruan tinggi di Yogyakarta, yang mungkin tidak dapat digeneralisir untuk program studi dari perguruan tinggi di luar Yogyakarta. Untuk penelitian mendatang penulis merekomendasikan untuk melakukan perbandingan antara kualitas jasa pendidikan tinggi di Yogyakarta yang dikenal sebagai kota pelajar dengan program studi dari perguruan tinggi di kota selain Yogyakarta.

\section{DAFTAR PUSTAKA}

Andalep, S.S. dan Basu, K.A. (1994), 'Technical Complexity and Consumer Knowledge as Moderators of Service Quality Evaluation in Automobile Service Industry', Journal of Retailing, Vol.70, No.4:367-381.

Aquilano (1992), Production and Operation Management, Sixth Edition, IRWIN, Boston. 
Babakus, E. dan Boller (1992),'An Empirical Assesment of The SERVQUAL Scale', Journal of Business Research, Vol. 24: 253-268.

Badan Akreditasi Nasional Perguruan Tinggi (1998), Akreditasi Program Studi Jenjang Sarjana (S1) Hasil Penilaian Tahun 1996/1997, Direktori Umum Departemen Pendidikan dan Kebudayaan.

Bounds, G., Yorks, L., Adams, M. dan Ranney, G. (1994), Beyond Total Quality Management, Toward the Emerging Paradigm, McGrawhill Inc, New York.

Cooper, R.D. dan Emory, W.C. (1996), Business Research Methods, Irwin, Boston.

Crosby, P.B. (1979), Quality is Free The Art of Making Quality Certain, Mc Graw Hill Book Company.

Cronin, J.J. dan Taylor, A.S. (1992), 'Measuring Service Quality: A Reexamination and Extension', Journal of Marketing, Vol. 56: 55-68.

Dabholkar, A.P., Thorpe, I.D. dan Rentz, O.J. (1996), 'A Measure of Service Quality for Retail Store Scale Development and Validition', Journal of the Academy Marketing Science, Vol. 24, No.1:3-16.

Deming, E.W. (1992), Out of Crisis, Massachusetts Institute of Technology, Cambridge, Mass.

Feigenbaum, A.V. (1983), Total Quality Control, third edition, Mc Graw Hill Book Company.

Freeman, D.K. dan Dart, J. (1993), 'Measuring the Perceived Quality of Professional Business Services', Journal of Professional Services Marketing, Vol.9, No.1.

Handriana, T. (1998), 'Analisis Perbedaan Harapan Kualitas Jasa Pada Lembaga Pendidikan Tinggi di Surabaya', Tesis $S_{2}$.

Kettinger, J.W. dan Lee, C.C. (1994), 'Perceived Service Quality and User Satisfaction with the Information Services Function', Decision Science, Vol. 23, №. 5/6:737-766.

Krawjewsky, J. L. dan Ritzman, P. L. (1996), Operation Management, Fourth edition, Addison-Wesley Publishing Company.

Musa, S. (1996), 'TQS in Private and Public Multimedia Organization A comparative Analysis of the Television Broadcasting Industry Indonesia', Tesis $S_{2}$.

Nunnally, C.J. (1967), Psychometric Theory, McGraw-Hillseriesin. 
Parasuraman, Zeithaml, A.V. dan Berry L.L. (1985), 'A Conceptual model of Service Quality', Journal of Retailing, Vol. 67: 420-450.

Parasuraman, Zeithaml, A.V. dan Berry L.L. (1994), ' Reassesment of Expectations as a Comparison Standar in Measuring Service Quality: Implications for Further Research', Journal of Marketing, Vol. 9:111-124.

Pitt, F.L. (1995), 'Service Quality: A Measure of Information System Effectiveness', MIS Quarterly, June: 172-187.

Qamari, N.I. (1998), 'Evaluasi Kualitas Jasa Rumah sakit dan Penerapan Konsep QFD (Studi berbagai Rumah Sakit di DIY)', Tesis $S_{2}$.

Russel, R. dan Taylor III, W.B. (1995), Production and Operations Management Focusing on Quality dan Competitiveness, Prentice Hall.

Singarimbun, M. (1989), Metode Penelitian Survey, Edisi ke-2, LP3ES.

Sekaran, U. (1992), Research Methods for Business A Skill Building Approach, second edition, John Wiley \& Sons, Inc, New York.

Sulistyo, H. (1998),'Hubungan Antara Kualitas Jasa dan Kepuasan Pelanggan Dalam Pembentukan Intensi Pembelian Konsumen, Studi pada Empat Industri Jasa Di Semarang', Tesis $S_{2}$.

Shafer, M .S. dan Meredith, R .J. (1998), Operation Management, John Wiley dan Sons Inc: 739- 769.

Sconberger, J.R. dan Knod, M.E. (1997), Operations Management Customer-Focused Prinsiples, Sixth Edition, IRWIN, Chicago.

Subiyakto, H.H. (1999), 'Ukuran Kualitas Jasa: Gap Antara Kinerja dan Harapan atau Kinerja?', Wahana, Vol.2, No.1.

Stamatis, D.H. (1996), Total Quality Service, St Lucie Press, U.S.A.

Taguchi, G. (1987), System of Experimental Design (Vol.1-2). UNIPUB/Kraus International Publications, White Plains, N.Y.

Teas, K.R. (1994), 'Expectations as a Comparison Standard in Measuring Service Quality: An Assesment of Reassesment', Journal of Marketing, Vol.58: 132-139.

Tjiptono, F. (1999), 'Kualitas Jasa: Pengukuran, Keterbatasan dan Implikasi Manajerial', Usahawan, No. 03: 30-33.

Zeithaml, A. (1988), 'Consumer Perceptions of Price, Quality, and Value: a Means-End Model and Synthesis of Evidence', Journal of Marketing, Vol. 52: 2-22. 
Zeithaml, A.V., Berry L.L. dan Parasuraman, A. (1988), 'Communication and Control Processes in the Delivery of Service Quality', Journal of Marketing, Vol. 52: 35-48.

Zeithaml, A.V., Berry L.L., dan Parasuraman, A. (1993), 'The Nature and Determinants of Customer Expectations of Services', Journal of Academy Marketing Science, Vol. 21. No.1: 1-12. 